\title{
Quality of meat from young crossbred bulls frozen after 14 days of modified atmosphere storage
}

\author{
Katarzyna Śmiecińska, Tomasz Daszkiewicz, Dorota Kubiak, Natalia Piaskowska and Sylwia Łojewska \\ University of Warmia and Mazury in Olsztyn, Faculty of Animal Bioengineering. \\ Department of Commodity Science and Animal Raw Material Processing, \\ Oczapowskiego 5, 10-719 Olsztyn, Poland \\ e-mail: katarzyna.smiecinska@uwm.edu.pl
}

\begin{abstract}
The quality of the longissimus lumborum muscle (Holstein-Friesian Black-and-White- HF BW x Belgian Blue - BB bulls) was determined after 14 days of storage under different modified atmospheres (MA) (vacuum; $40 \% \mathrm{CO}_{2}+60 \% \mathrm{~N}_{2}$; $30 \% \mathrm{CO}_{2}+70 \% \mathrm{Ar}$ ) and 6 months of frozen storage following 14 days of MA storage. Weight loss and cooking loss were smaller, and drip loss was greater after frozen storage compared with refrigerated storage. The $\mathrm{pH}$ of stored meat was typical of high-quality beef. TBARS values increased after refrigerated storage and after frozen storage. The changes in color parameters point to metmyoglobin formation in frozen meat. Both refrigerator and freezer storage had beneficial influence on tenderness, and shear force values decreased in frozen beef. The composition of MA during refrigerated storage had no effect on the analyzed parameters of beef. Frozen meat that was stored in a MA containing Ar prior to freezing was characterized by the lowest weight loss, and vacuum-packaged meat by the lowest TBARS values.
\end{abstract}

Key words: beef quality, physicochemical properties, sensory evaluation, lipid oxidation

\section{Introduction}

The development of desirable quality attributes of beef is determined by the fattening performance of cattle (Aldai et al. 2012, Peña et al. 2013), meat packaging methods (Zhou et al. 2010, Arvanitoyannis and Stratakos 2012) and storage conditions (Farouk and Wieliczko 2003, Vieira et al. 2009, Zakrys et al. 2009, Olivera et al. 2013). The Belgian Blue (BB) is a beef cattle breed, which is characterized by muscular hypertrophy known as double muscling (DM). Muscular hypertrophy is caused by a natural mutation in the myostatin gene, responsible for and a higher rate of glycolytic metabolism, which is associated with a lower collagen content of muscles (Lepetit 2008, Dubost et al. 2013) and higher meat tenderness (Christensen et al. 2011, Purslow et al. 2012). Double-muscled animals and their crosses have a lower percentage content of fat (Cuvelier et al. 2006, Aldai et al. 2007), and a higher percentage content of protein (Keady et al. 2013) and unsaturated fatty acids (Wiener et al. 2009, Kim et al. 2010b).

Similarly to other perishable food products, meat is susceptible to natural and mostly irreversible physical, chemical, biochemical and microbiological changes that may deteriorate its functional and sensory properties. Meat must be stored in the refrigerator or freezer to extend its shelf life (Leygonie et al. 2012, Ngapo et al. 2012a, 2012b). However, the time of refrigerated and frozen storage of meat is limited due to progressive changes in its color, sensory quality and lipid oxidation (Viana et al. 2005, Brooks et al. 2008, Dransfield 2008). Weight loss caused by the drip during storage is another important consideration (Cayuela et al. 2004, Lagerstedt et al. 2008). Chilled storage affects also the meat aging process aimed at achieving the consumer-desired attributes (Lindahl et al. 2010, Li et al. 2012). The quality of fresh packaged meat is largely determined by its type, the time of cold storage, gas mixture composition, the type of packaging and storage temperature (McMillin 2008, Zhou et al. 2010). Surplus meat can be preserved by freezing, and frozen meat can be exported worldwide. The quality of frozen meat is affected by both primary and secondary changes that occur at successive stages of freezing and storage (Leygonie et al. 2012). Storage methods should be adjusted to the key characteristics of meat products, and should be selected in view of the fact that certain changes occur during storage and influence the ultimate quality of meat.

The aim of this study was to evaluate the quality of meat (weight loss during storage, water-holding capacity WHC, pH, lipid oxidation, color, sensory properties, shear force values) from young crossbred (Holstein-Friesian Black-and-White - HF BW x Belgian Blue - BB) bulls. The quality of the longissimus lumborum (LL) muscle was determined after 14 days of refrigerated storage under different modified atmospheres (MA) (vacuum; $40 \% \mathrm{CO}_{2}+$ $60 \% \mathrm{~N}_{2} ; 30 \% \mathrm{CO}_{2}+70 \% \mathrm{Ar}$ ) and 6 months of frozen storage following 14 days of MA storage. 


\section{Materials and methods}

\section{Animals and experimental materials}

The experimental materials comprised 10 carcasses of $F_{1}$ bulls produced by crossing HF BW and BB cattle. All animals were the offspring of double-muscled sires. Young bulls were raised indoor on the same farm and were fed farm-made feed. In autumn and winter, they received hay ad libitum, maize silage and ground cereal grain (approx. $2 \mathrm{~kg}$ ). In summer, they were fed green forage ad libitum, ground cereal grain and hay. The bulls were transported to a meat processing plant over a distance of approximately $90 \mathrm{~km}$. On arrival, their average body weight was 762 $\pm 47 \mathrm{~kg}$. Before slaughter, they stayed in lairage, in individual pens, for around $18 \mathrm{~h}$. The bulls were slaughtered in September, at 23 months of age. Average hot carcass weight was $447 \pm 42 \mathrm{~kg}$. After weighing, the carcasses were chilled at a temperature of $1-4{ }^{\circ} \mathrm{C}$ for $48 \mathrm{~h}$. During carcass dressing, the lumbar segments of the right musculus longissimus dorsi (LD) between the last but one and the last thoracic vertebrae, and the last lumbar vertebra, i.e. musculus longissimus lumborum (LL), were collected. The samples were weighed, vacuum-packaged and transported to the laboratory in isothermal containers. In the laboratory, LL muscles were divided into 4 parts of similar weight (approx. $1500 \mathrm{~g}$ ), which were further divided into 4 groups: $A-A^{1}, B-B^{1}, C-C^{1}$ and $D-D^{1}$ (Fig. 1).

LL muscle
\begin{tabular}{|c|c|c|c|c|c|c|c|}
\cline { 3 - 6 } & \multicolumn{7}{c}{ Randomization order } \\
\hline A & $A^{1}$ & $B$ & $B^{1}$ & $C$ & $C^{1}$ & $D$ & $D^{1}$ \\
\hline
\end{tabular}
thoracic region

Fig. 1. Division of musculus longissimus lumborum into samples intended for refrigerated and frozen storage

Samples A were subjected to laboratory analyses immediately after collection (approx. $54 \mathrm{~h}$ post mortem), and samples A1 were vacuum-packaged and frozen on arrival at the laboratory. Samples B-B ${ }^{1}$ were vacuum-packaged and stored for 14 days in the refrigerator; next, all samples were unpackaged, samples B were subjected to analyses and samples $B^{1}$ were vacuum-packaged and frozen. Samples $C_{-} C^{1}$ were packaged under MA composed of $40 \%$ $\mathrm{CO} 2+60 \% \mathrm{~N} 2$, and were stored for 14 days in the refrigerator; next, all samples were unpackaged, samples C were subjected to analyses and samples $C^{1}$ were vacuum-packaged and frozen. Samples D-D ${ }^{1}$ were packaged under MA composed of $30 \% \mathrm{CO}_{2}+70 \% \mathrm{Ar}$, and were stored for 14 days in the refrigerator; next, all samples were unpackaged, samples $D$ were subjected to analyses and samples $D^{1}$ were vacuum-packaged and frozen.

Meat samples were packaged in bags made of ethylene-vinyl alcohol (EVOH) copolymer with enhanced gas barrier performance, with the use of the PP15 (MGO) Tepro Vacu Tronic 2000 vacuum packaging machine (Tepro S.A.). Before freezing, samples $B, C$ and $D$ were stored in a Freon refrigerating chamber without forced air-flow at a temperature of $2^{\circ} \mathrm{C}$ for 14 days. Relative air humidity in the chamber was $50 \%$.

Samples $A^{1}$ (immediately after collection), and samples $B^{1}, C^{1}$ and $D^{1}$ (after 14 days of refrigerated MA storage) were vacuum-packaged and frozen at $-26^{\circ} \mathrm{C}$ (quick freezing, $5-20 \mathrm{~cm} \mathrm{~h}^{-1}$ ), and were stored at this temperature for 6 months. The samples were frozen and freezer-stored in a Freon freezing chamber with a digital temperature control system. At the end of the freezer-storage period, meat samples were thawed in the air at a temperature of $2{ }^{\circ} \mathrm{C}$, in a refrigerating chamber with air flow control, until the temperature at the geometric center of the sample reached $4 \pm 2{ }^{\circ} \mathrm{C}$. The time of freezing and thawing was comparable. Thawed samples were analyzed to determine their quality attributes.

\section{Analytical procedures}

Samples intended for analyses of $\mathrm{pH}$ and water-holding capacity (forced drip) were passed three times through a $3 \mathrm{~mm}$ plate in a meat grinder, and were thoroughly mixed. Weight loss after refrigerated and frozen storage was determined based on the difference in weight before and after storage. The results were expressed as a percentage relative to initial weight. Drip loss and cooking loss were determined as described by Honikel (1998). The water-holding capacity of meat (forced drip) was determined by the method proposed by Grau and Hamm (van Oeckel et al. 1999). The $\mathrm{pH}$ of each sample was measured in the water homogenates of meat (10 $\mathrm{g}$ of meat was homogenized with $10 \mathrm{ml}$ of distilled water using an IKA Ultra Turrax ${ }^{\circ}$ T25 digital homogenizer at around 1/4 speed with $3 \times 5$ s bursts), using a combination Polilyte Lab electrode (Hamilton) and an inoLab Level2 pH-meter equipped with a TFK 325 temperature sensor (WTW). 
K. Śmiecińska et al. (2018) 27: 243-254

The extent of lipid oxidation was estimated based on TBARS values (Pikul et al. 1989). Absorbance was measured with the Specord ${ }^{\circledR} 40$ spectrophotometer (Analytik Jena AG, Jena, Germany) at a wavelength of $532 \mathrm{~nm}$, and TBARS values were expressed in $\mathrm{mg}$ of malondialdehyde (MDA) per kg of meat.

Meat color was determined based on the values of CIELAB coordinates, L* (lightness), a* (redness), b*(yellowness), $C^{*}$ (chroma) and $h^{\circ}$ (hue angle) (CIE 1978). Color space parameters $L^{*}, a^{*}$ and $b^{*}$ were measured three times by the reflectance method using a HunterLab MiniScan XE Plus spectrocolorimeter (Hunter Associates Laboratory Inc., Reston, VA, USA) with standard illuminant D65, a 10 standard observer angle and a 2.54-cm-diameter aperture, at different points over the muscle cross-section area. The apparatus was standardized using black and white standard plates. The values of $C^{*}$ were calculated from the following formula: $C^{*}=\left(a^{* 2}+b^{* 2}\right)^{1 / 2}$. The values of $h^{\circ}$ were calculated from the following formula: $h^{\circ}=\tan ^{-1}(b \div a)$.

The sensory properties of cooked meat (Baryłko-Pikielna et al. 1964) were evaluated by five trained panelists, previously selected for their flavor and texture sensitivity (ISO 2012). Prior to sample evaluation, the panelists participated in orientation sessions to familiarize themselves with the sensory properties of cooked beef. Meat was cooked in a $0.6 \% \mathrm{NaCl}$ solution (meat to solution weight ratio of $1: 2$ ) at $96 \pm 2{ }^{\circ} \mathrm{C}$. The ultimate temperature inside the sample was $80^{\circ} \mathrm{C}$. Approximately $1 \mathrm{~cm}^{3}$ cubes of meat were cut from the middle of each cooked sample and wrapped in aluminum foil. Coded meat samples were presented to the panelists under fluorescent light, at room temperature. The samples were presented individually. Distilled water was made available to the panelists for mouth cleansing between samples. All sensory attributes (aroma, taste, juiciness and tenderness) of each sample were evaluated during a single session. A maximum of five meat samples were assessed per session (Daszkiewicz et al. 2015). Numerical scaling (5-point-scale) was used to express the intensity and desirability of traits (Daszkiewicz et al. 2012).

The shear force of meat was determined using a Warner-Bratzler head ( $500 \mathrm{~N}$, speed $100 \mathrm{~mm} \mathrm{~min}^{-1}$.) attached to an Instron universal testing machine (model 5542). Meat samples were prepared and shear force was measured as described by Honikel (1998).

\section{Statistical analyses}

STATISTICA software, version 12.0 (StatSoft, Inc., 2012) was used for statistical analysis. The data were processed by one-way ANOVA. Duncan's test was applied to estimate the significance of differences ( $p \leq 0.05$ and $p \leq 0.01)$ in meat quality parameters between meat samples.

\section{Results \\ Weight loss and water-holding capacity of meat}

Refrigerated MA storage for 14 days had no significant $(p>0.05)$ effect on weight loss in the analyzed meat samples $(B, C, D)$ (Table 1). Weight loss was greater $(p \leq 0.05)$ in meat samples frozen without prior refrigerated storage $\left(A^{1}\right)$ than in those frozen after storage in MA composed of $40 \% \mathrm{CO}_{2}+60 \% \mathrm{~N}_{2}\left(C^{1}\right)$. Weight loss was smaller $(p \leq 0.01)$ in meat samples frozen after storage in $M A$ containing $\operatorname{Ar}\left(D^{1}\right)$ than in those frozen without prior refrigerated storage $\left(A^{1}\right)$ and vacuum-packaged before freezing $\left(B^{1}\right)$. Greater $(p \leq 0.01)$ weight loss was observed in meat samples stored in the refrigerator $(C$ and $D)$ than in those stored in the freezer $\left(C^{1}\right.$ and $\left.D^{1}\right)$.

Meat samples that were not subjected to refrigerated MA storage (A) were characterized by greater $(p \leq 0.01)$ drip loss than the remaining samples $(B, C, D)$ (Table 1$)$. Drip loss was greater $(p \leq 0.01)$ in meat samples frozen immediately $\left(A^{1}\right)$ than in those frozen after $M A$ storage $\left(B^{1}, C^{1}, D^{1}\right)$. Average drip loss values before freezing $(A, B, C, D)$ were lower $(p \leq 0.01)$ than those noted in the same groups $\left(A^{1}, B^{1}, C^{1}, D^{1}\right)$ after frozen storage.

Fresh meat samples $(A)$ were characterized by smaller $(p \leq 0.01)$ cooking loss than samples stored for 14 days in MA composed of $40 \% \mathrm{CO}_{2}+60 \% \mathrm{~N}_{2}$ (C) (Table 1). No significant $(p>0.05)$ differences in cooking loss were found between samples evaluated after frozen storage. Greater $(p \leq 0.01)$ cooking loss was observed in samples stored under different $M A$ conditions $(B, C, D)$ compared with those stored in the freezer $\left(B^{1}, C^{1}, D^{1}\right)$.

Storage under various MA conditions had no significant $(p>0.05)$ influence on the water-holding capacity of meat determined by the Grau and Hamm method (Table 1). Greater drip loss was noted in meat samples frozen immediately $\left(A^{1}\right)$ than in those frozen after 14 days of storage in vacuum packages $\left(B^{1}\right)(p \leq 0.01)$ and in MA composed of $40 \% \mathrm{CO}_{2}+60 \% \mathrm{~N}_{2}\left(C^{1}\right)(p \leq 0.05)$. The average water-holding capacity of meat before freezing $(A, B, C, D)$ was not significantly $(p>0.05)$ different from the values noted after frozen storage $\left(A^{1}, B^{1}, C^{1}, D^{1}\right)$. 
Table 1. Weight loss and water-holding capacity of meat

\begin{tabular}{|c|c|c|c|c|c|}
\hline \multirow{4}{*}{ Specification } & \multirow{4}{*}{ Time of laboratory analyses } & \multicolumn{4}{|c|}{ Beef processing } \\
\hline & & $\begin{array}{c}\text { Non-cold stored } \\
\text { beef }\end{array}$ & $\begin{array}{l}\text { Vacuum- } \\
\text { packaged beef } \\
\text { stored in the } \\
\text { refrigerator for } \\
14 \text { days }\end{array}$ & $\begin{array}{c}\text { Beef stored in } \\
\text { the refrigerator } \\
\text { for } 14 \text { days in } \\
\text { MA composed } \\
\text { of } 40 \% \mathrm{CO}_{2}+ \\
60 \% \mathrm{~N}_{2}\end{array}$ & $\begin{array}{c}\text { Beef stored in } \\
\text { the refrigerator } \\
\text { for } 14 \text { days in } \\
\mathrm{MA} \text { composed } \\
\text { of } 30 \% \mathrm{CO}_{2}+ \\
70 \% \mathrm{Ar}^{2}\end{array}$ \\
\hline & & A & B & C & D \\
\hline & & $A^{1}$ & $\mathrm{~B}^{1}$ & $\mathrm{C}^{1}$ & $\mathrm{D}^{1}$ \\
\hline \multirow{2}{*}{ Weight loss, \% } & before freezing & - & $2.18 \pm 0.26$ & $2.60^{x} \pm 0.29$ & $2.46^{x} \pm 0.33$ \\
\hline & after frozen storage & $2.30^{\mathrm{Aa}} \pm 0.25$ & $1.95^{B} \pm 0.27$ & $1.63^{a x} \pm 0.12$ & $1.13^{\mathrm{ABX}} \pm 0.12$ \\
\hline \multirow{2}{*}{ Drip loss, \% } & before freezing & $2.71^{\mathrm{ABCX}} \pm 0.48$ & $0.84^{\mathrm{AX}} \pm 0.07$ & $0.86^{B X} \pm 0.11$ & $0.98^{c x} \pm 0.13$ \\
\hline & after frozen storage & $9.47^{\mathrm{ABCX}} \pm 1.24$ & $3.76^{A x} \pm 0.86$ & $4.36^{\mathrm{BX}} \pm 0.80$ & $5.61^{c x} \pm 0.78$ \\
\hline \multirow{2}{*}{ Cooking loss, \% } & before freezing & $34.81^{\mathrm{A}} \pm 0.88$ & $36.41^{x} \pm 0.63$ & $37.10^{A x} \pm 0.68$ & $36.81^{x} \pm 0.53$ \\
\hline & after frozen storage & $34.78 \pm 0.67$ & $33.27^{x} \pm 0.63$ & $32,79^{x} \pm 0,78$ & $33.70^{x} \pm 0.52$ \\
\hline Water-holding capacity & before freezing & $6.24 \pm 0.31$ & $5.83 \pm 0.30$ & $5.81 \pm 0.41$ & $5.74 \pm 0.21$ \\
\hline $\begin{array}{l}\text { Grau and Hamm method, } \\
\mathrm{cm}^{2}\end{array}$ & after frozen storage & $6.73^{\mathrm{Aa}} \pm 0.26$ & $5.13^{A} \pm 0.31$ & $5.36^{\mathrm{a}} \pm 0.26$ & $5.90 \pm 0.57$ \\
\hline
\end{tabular}

Values are reported as means \pm SEM; Values in the same row with the same letters are significantly different: $a(p \leq 0.05) ; A, B, C(p \leq 0.01)$; Values in the same column with the same letters are significantly different: $\mathrm{X}(p \leq 0.01)$

\section{$\mathrm{pH}$ of meat}

No significant $(p>0.05)$ differences in the average $\mathrm{pH}$ values of meat were found between groups $(A, B, C, D)$ before freezing (Table 2). The average $\mathrm{pH}$ of meat samples frozen without prior MA storage $\left(\mathrm{A}^{1}\right)$ was lower $(p \leq 0.05)$ compared with that noted in the remaining groups $\left(B^{1}, C^{1}, D^{1}\right)$. No significant $(p>0.05)$ differences in the average $\mathrm{pH}$ values of meat were observed between the corresponding groups evaluated before freezing $(A, B, C, D)$ and after frozen storage $\left(A^{1}, B^{1}, C^{1}, D^{1}\right)$.

Table 2. $\mathrm{pH}$ of meat and TBARS values

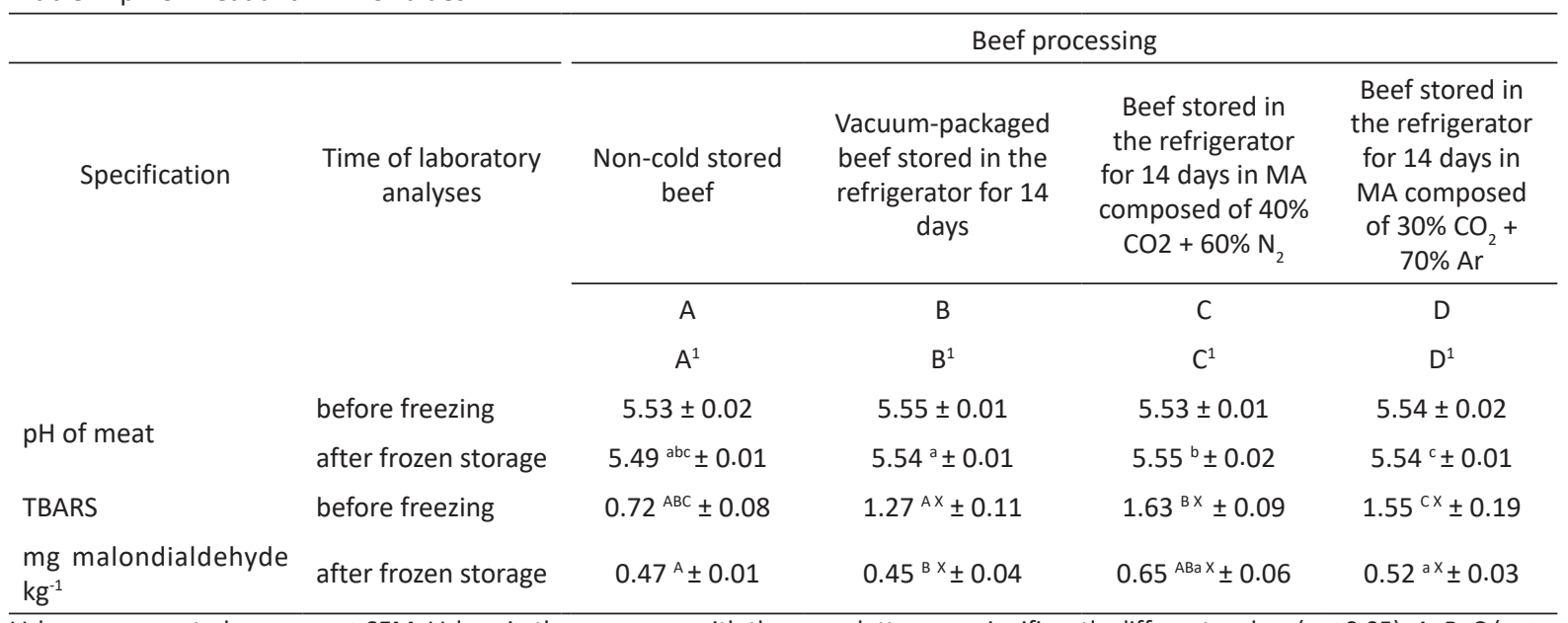

Values are reported as means \pm SEM; Values in the same row with the same letters are significantly different: $a, b, c(p \leq 0.05) ; A, B, C(p \leq$ $0.01)$; Values in the same column with the same letters are significantly different: $X(p \leq 0.01)$

\section{Lipid oxidation (TBARS value)}

TBARS values were lower $(p \leq 0.01)$ in meat samples evaluated post mortem $(A)$ than in those stored under MA (B, $C, D)$ (Table 2). In comparison with meat samples frozen after 14 days of storage in $\mathrm{MA}$ composed of $40 \% \mathrm{CO}_{2}+$ $60 \%\left(C^{1}\right)$, samples frozen immediately $\left(A^{1}\right)(p \leq 0.01)$ and those stored in vacuum packages $\left(B^{1}\right)(p \leq 0.01)$ and in $M A$ containing $\operatorname{Ar}\left(D^{1}\right)(p \leq 0.05)$ had lower TBARS levels. Meat samples evaluated after refrigerated storage under MA $(B, C, D)$ had higher $(p \leq 0.01)$ TBARS values than those analyzed after frozen storage $\left(B^{1}, C^{1}, D^{1}\right)$. 


\section{Color parameters of meat}

Beef handling before freezing had no significant effect on the color lightness ( $L^{*}$ ) of samples (A, B, C, D) (Table 3). Meat samples frozen immediately $\left(A^{1}\right)$ were darker in color $(p \leq 0.05)$ than those frozen after storage in vacuum packages $\left(B^{1}\right)$. No significant $(p>0.05)$ differences in average $L^{*}$ values were found between the corresponding groups evaluated before freezing $(A, B, C, D)$ and after frozen storage $\left(A^{1}, B^{1}, C^{1}, D^{1}\right)$.

Meat samples that were not stored before freezing $(A)$ were characterized by a lower $(p \leq 0.01)$ contribution of redness $\left(a^{*}\right)$ than those stored under MA $(B, C, D)$ (Table 1$)$. Samples that were frozen immediately $\left(A^{1}\right)$ had a higher contribution of redness $\left(a^{*}\right)(p \leq 0.01)$ than those frozen after 14 days of storage in $M A\left(B^{1}, C^{1}, D^{1}\right)$. In all analyzed groups, higher $(p \leq 0.01) a^{*}$ values were noted before freezing $(A, B, C, D)$ than after frozen storage $\left(A^{1}, B^{1}, C^{1}, D^{1}\right)$.

Average $b^{*}$ values were lower $(p \leq 0.01)$ in fresh meat before freezing $(A)$ than in meat stored in the refrigerator in vacuum packages (B) and in MA packages containing $40 \% \mathrm{CO}_{2}+60 \% \mathrm{~N}_{2}$ (C) and $\mathrm{Ar}(\mathrm{D})(p \leq 0.05)$ (Table 3). No significant $(p>0.05)$ differences in the contribution of yellowness $\left(b^{*}\right)$ were found between meat samples evaluated after storage in the freezer. Similarly to parameter $a^{*}$, meat samples analyzed before freezing $(A, B, C, D)$ had a higher contribution of yellowness $(p \leq 0.01)$ than those evaluated after frozen storage $\left(A^{1}, B^{1}, C^{1}, D^{1}\right)$.

Chroma $\left(C^{*}\right)$ values were lower $(p>0.05)$ in fresh beef $(A)$ than in samples stored under MA $(B, C, D)($ Table 3$)$. Color saturation was higher $(p \leq 0.01)$ in meat frozen immediately $\left(A^{1}\right)$ than in meat frozen after storage under $M A$ $\left(B^{1}, C^{1}, D^{1}\right)$. The values of parameter $C^{*}$ were higher $(p \leq 0.01)$ before freezing (samples $\left.A, B, C, D\right)$ than after storage in the freezer (samples $A^{1}, B^{1}, C^{1}, D^{1}$ ).

No significant $(p>0.05)$ differences in hue angle $\left(h^{\circ}\right)$ values were observed between meat samples before freezing (Table 3). Beef frozen without prior refrigerated storage $\left(A^{1}\right)$ had lower $(p \leq 0.01) h^{\circ}$ values than the remaining samples $\left(B^{1}, C^{1}\right.$ and $\left.D^{1}\right)$. Average hue angle $\left(h^{\circ}\right)$ values were lower $(p \leq 0.01)$ in meat frozen immediately $\left(A^{1}\right)$ than in fresh meat $(A)$. in the remaining groups, $h^{\circ}$ values were higher in meat samples stored in the freezer $\left(B^{1}, C^{1}\right.$ and $\left.D^{1}\right)$ than in those stored in the refrigerator (B, C and D).

Table 3. Meat color parameters

\begin{tabular}{|c|c|c|c|c|c|}
\hline & & & Beef $p$ & cessing & \\
\hline \multirow[t]{3}{*}{ Specification } & \multirow[t]{3}{*}{$\begin{array}{c}\text { Time of laboratory } \\
\text { analyses }\end{array}$} & $\begin{array}{c}\text { Non-cold stored } \\
\text { beef }\end{array}$ & $\begin{array}{l}\text { Vacuum-packaged } \\
\text { beef stored in the } \\
\text { refrigerator for } 14 \\
\text { days }\end{array}$ & $\begin{array}{l}\text { Beef stored in the } \\
\text { refrigerator for } 14 \text { days } \\
\text { in } \mathrm{MA} \text { composed of } \\
40 \% \mathrm{CO}_{2}+60 \% \mathrm{~N}_{2}\end{array}$ & $\begin{array}{c}\text { Beef stored in } \\
\text { the refrigerator } \\
\text { for } 14 \text { days in } \mathrm{MA} \\
\text { composed of } 30 \% \\
\mathrm{CO}_{2}+70 \% \mathrm{Ar}\end{array}$ \\
\hline & & A & B & C & $\mathrm{D}$ \\
\hline & & $A^{1}$ & $\mathrm{~B}^{1}$ & $\mathrm{C}^{1}$ & $D^{1}$ \\
\hline \multirow{2}{*}{ L* lightness } & before freezing & $35.36 \pm 1.08$ & $36.16 \pm 1.61$ & $35.27 \pm 1.40$ & $36.59 \pm 1.79$ \\
\hline & after frozen storage & $36.59 a \pm 0.89$ & $40.27 a \pm 1.30$ & $38.40 \pm 1.24$ & $39.40 \pm 0.89$ \\
\hline \multirow{2}{*}{$a^{*}$ redness } & before freezing & $19.26^{\mathrm{ABCX}} \pm 0.74$ & $23.77^{\mathrm{AX}} \pm 0.38$ & $23.33^{\mathrm{BX}} \pm 0.41$ & $22.21^{c x} \pm 0.56$ \\
\hline & after frozen storage & $13.29^{\mathrm{ABCX}} \pm 0.50$ & $10.06^{A x} \pm 0.54$ & $9.93^{\mathrm{BX}} \pm 0.54$ & $10.01^{c x} \pm 0.47$ \\
\hline \multirow{2}{*}{ b* yellowness } & before freezing & $20.99^{A B C X} \pm 1.03$ & $24.39^{A X} \pm 0.19$ & $24.12^{\mathrm{BX}} \pm 0.24$ & $23.14^{c x} \pm 0.37$ \\
\hline & after frozen storage & $11.83^{x} \pm 0.32$ & $12.16^{x} \pm 0.36$ & $11.44^{x} \pm 0.21$ & $12.34^{x} \pm 0.31$ \\
\hline \multirow{2}{*}{ C* chroma } & before freezing & $28.73^{\mathrm{ABCX}} \pm 1.04$ & $34.06^{A X} \pm 0.40$ & $33.57^{\mathrm{BX}} \pm 0.44$ & $32.98^{c x} \pm 0.90$ \\
\hline & after frozen storage & $17.83^{\mathrm{ABCX}} \pm 0.49$ & $15.84^{\mathrm{AX}} \pm 0.48$ & $15.19^{\mathrm{BX}} \pm 0.41$ & $15.94^{c x} \pm 0.38$ \\
\hline \multirow{2}{*}{$h^{\circ}$ hue angle } & before freezing & $46.82^{x} \pm 1.02$ & $45.77^{x} \pm 0.28$ & $45.98^{\times} \pm 0.29$ & $46.22^{x} \pm 0.32$ \\
\hline & after frozen storage & $41.79^{\mathrm{ABCX}} \pm 1.13$ & $50.61^{A x} \pm 1.58$ & $49.41^{B x} \pm 1.51$ & $51.07^{c x} \pm 1.53$ \\
\hline
\end{tabular}

Values are reported as means \pm SEM; Values in the same row with the same letters are significantly different: a, c ( $p \leq 0.05) ; \mathrm{A}, \mathrm{B}, \mathrm{C}(p \leq 0.01)$; Values in the same column with the same letters are significantly different: $\mathrm{X}(p \leq 0.05) ; \mathrm{X}(p \leq 0.01)$

\section{Sensory properties and shear force values}

No significant $(p>0.05)$ differences in the aroma intensity of beef were observed before freezing (Table 4). Meat samples frozen immediately $\left(A^{1}\right)$ received lower $(p \leq 0.05)$ scores for aroma than those frozen after storage in vacuum packages $\left(\mathrm{B}^{1}\right)$ and under MA composed of $40 \% \mathrm{CO}_{2}+60 \% \mathrm{~N}_{2}\left(\mathrm{C}^{1}\right)$. Fresh meat $(A)$ scored higher $(p \leq 0.01)$ for aroma intensity than freezer-stored meat $\left(A^{1}\right)$. 
Storage under different MA conditions and in the freezer had no significant $(p>0.05)$ influence on the aroma desirability of beef (Table 4). Fresh meat (A) $(p \leq 0.01)$ and meat stored in vacuum packages (B) $(p \leq 0.01)$ and in $M A$ containing $\operatorname{Ar}(D)(p \leq 0.05)$ scored higher for aroma desirability than the respective samples evaluated after frozen storage $\left(A^{1}, B^{1}, D^{1}\right)$.

Neither beef handling before freezing nor storage in the freezer exerted significant $(p>0.05)$ effects on taste intensity (Table 4$)$. Storage under MA had no influence $(p>0.05)$ on taste desirability. After frozen storage, higher $(p \leq 0.05)$ flavor desirability was noted in meat samples that were stored in $\mathrm{MA}$ composed of $30 \% \mathrm{CO}_{2}+70 \% \mathrm{Ar}$ before freezing $\left(D^{1}\right)$ compared with those stored in vacuum packages $\left(B^{1}\right)$. Meat samples were characterized by higher $(p \leq 0.01)$ taste desirability before freezing $(A, B, C)$ than after frozen storage $\left(A^{1}, B^{1}, C^{1}\right)$.

Table 4. Aroma and taste of meat

\begin{tabular}{|c|c|c|c|c|c|}
\hline \multirow[b]{2}{*}{ Specification } & \multirow[b]{2}{*}{$\begin{array}{c}\text { Time of laboratory } \\
\text { analyses }\end{array}$} & \multicolumn{4}{|c|}{ Beef processing } \\
\hline & & $\begin{array}{l}\text { Non-cold } \\
\text { stored beef }\end{array}$ & $\begin{array}{l}\text { Vacuum-packaged } \\
\text { beef stored in the } \\
\text { refrigerator for } 14 \\
\text { days }\end{array}$ & $\begin{array}{c}\text { Beef stored in } \\
\text { the refrigerator } \\
\text { for } 14 \text { days in } \mathrm{MA} \\
\text { composed of } 40 \% \\
\mathrm{CO}_{2}+60 \% \mathrm{~N}_{2}\end{array}$ & $\begin{array}{c}\text { Beef stored in } \\
\text { the refrigerator } \\
\text { for } 14 \text { days in } \\
\mathrm{MA} \text { composed } \\
\text { of } 30 \% \mathrm{CO}_{2}{ }^{+} \\
70 \% \mathrm{Ar}^{2}\end{array}$ \\
\hline & & A & B & C & $\mathrm{D}$ \\
\hline & & $A^{1}$ & $\mathrm{~B}^{1}$ & $\mathrm{C}^{1}$ & $\mathrm{D}^{1}$ \\
\hline \multirow{2}{*}{ Aroma intensity, points } & before freezing & $4.75^{x} \pm 0.08$ & $4.75 \pm 0.08$ & $4.80 \pm 0.08$ & $4.65 \pm 0.08$ \\
\hline & after frozen storage & $4.30^{a b x} \pm 0.08$ & $4.60^{\mathrm{a}} \pm 0.07$ & $4.65^{b} \pm 0.13$ & $4.50 \pm 0.11$ \\
\hline \multirow{2}{*}{ Aroma desirability, points } & before freezing & $4.80^{x} \pm 0.08$ & $4.80^{x} \pm 0.11$ & $4.80 \pm 0.11$ & $4.95^{x} \pm 0.05$ \\
\hline & after frozen storage & $4.30^{x} \pm 0.11$ & $4.30^{x} \pm 0.15$ & $4.55 \pm 0.12$ & $4.60^{x} \pm 0.12$ \\
\hline \multirow{2}{*}{ Taste intensity, points } & before freezing & $4.75 \pm 0.08$ & $4.70 \pm 0.11$ & $4.70 \pm 0.08$ & $4.85 \pm 0.08$ \\
\hline & after frozen storage & $4.50 \pm 0.11$ & $4.45 \pm 0.12$ & $4.40 \pm 0.15$ & $4.65 \pm 0.11$ \\
\hline \multirow{2}{*}{ Taste desirability, points } & before freezing & $4.85^{x} \pm 0.08$ & $4.85^{x} \pm 0.08$ & $4.90^{x} \pm 0.07$ & $4.85 \pm 0.08$ \\
\hline & after frozen storage & $4.45^{x} \pm 0.12$ & $4.35^{\mathrm{ax}} \pm 0.11$ & $4.40^{x} \pm 0.12$ & $4.70^{\mathrm{a}} \pm 0.08$ \\
\hline
\end{tabular}

Values are reported as means \pm SEM; Values in the same row with the same letters are significantly different: $a, b(p \leq 0.05)$; Values in the same column with the same letters are significantly different: $\mathrm{x}(p \leq 0.05) ; \mathrm{X}(p \leq 0.01)$

An analysis of variance revealed that storage under different MA conditions and frozen storage exerted no significant $(p>0.05)$ effects on beef juiciness (Table 5).

Fresh beef evaluated before freezing (samples $A$ ) was less ( $p \leq 0.05$ ) tender than beef stored in MA composed of $40 \% \mathrm{CO}_{2}+60 \% \mathrm{~N}_{2}$ (C) (Table 5). Meat samples frozen immediately $\left(A^{1}\right)$ were less tender $(p \leq 0.05)$ than those frozen after storage in MA composed of $30 \% \mathrm{CO}_{2}+70 \% \operatorname{Ar}\left(D^{1}\right)$. No significant $(p>0.05)$ differences in average tenderness values were found between meat samples within the same groups before $(A, B, C, D)$ and after $\left(A^{1}, B^{1}\right.$, $\left.C^{1}, D^{1}\right)$ frozen storage.

Table 5. Juiciness, tenderness and shear force values of meat

\begin{tabular}{|c|c|c|c|c|c|}
\hline \multirow{4}{*}{ Specification } & \multirow{4}{*}{$\begin{array}{c}\text { Time of laboratory } \\
\text { analyses }\end{array}$} & \multicolumn{4}{|c|}{ Beef processing } \\
\hline & & $\begin{array}{c}\text { Non-cold stored } \\
\text { beef }\end{array}$ & $\begin{array}{l}\text { Vacuum-packaged } \\
\text { beef stored in the } \\
\text { refrigerator for } 14 \text { days }\end{array}$ & $\begin{array}{c}\text { Beef stored in } \\
\text { the refrigerator } \\
\text { for } 14 \text { days in } \mathrm{MA} \\
\text { composed of } 40 \% \\
\mathrm{CO}_{2}+60 \% \mathrm{~N}_{2}\end{array}$ & $\begin{array}{c}\text { Beef stored in } \\
\text { the refrigerator } \\
\text { for } 14 \text { days in } \mathrm{MA} \\
\text { composed of } 30 \% \\
\mathrm{CO}_{2}+70 \% \mathrm{Ar}\end{array}$ \\
\hline & & $A$ & B & C & $\mathrm{D}$ \\
\hline & & $A^{1}$ & $\mathrm{~B}^{1}$ & $\mathrm{C}^{1}$ & $\mathrm{D}^{1}$ \\
\hline \multirow{2}{*}{ Juiciness, points } & before freezing & $4.40 \pm 0.07$ & $4.60 \pm 0.10$ & $4.65 \pm 0.11$ & $4.65 \pm 0.11$ \\
\hline & after frozen storage & $4.50 \pm 0.11$ & $4.40 \pm 0.10$ & $4.45 \pm 0.16$ & $4.70 \pm 0.11$ \\
\hline \multirow{2}{*}{ Tenderness, points } & before freezing & $3.85^{\mathrm{a}} \pm 0.21$ & $4.35 \pm 0.18$ & $4.50^{a} \pm 0.17$ & $4.30 \pm 0.19$ \\
\hline & after frozen storage & $4.25^{a} \pm 0.11$ & $4.50 \pm 0.11$ & $4.45 \pm 0.16$ & $4.75^{a} \pm 0.11$ \\
\hline \multirow{2}{*}{ Shear force, $\mathrm{N}$} & before freezing & $33.68 \pm 2.86$ & $30.15^{x} \pm 2.00$ & $32.75^{x} \pm 2.73$ & $31.38 \pm 2.99$ \\
\hline & after frozen storage & $39.36^{\mathrm{ABC}} \pm 3.11$ & $18.01^{\mathrm{AX}} \pm 1.40$ & $21.70^{\mathrm{BX}} \pm 1.41$ & $24.34^{c} \pm 2.75$ \\
\hline
\end{tabular}

Values are reported as means \pm SEM; Values in the same row with the same letters are significantly different: a $(p \leq 0.05) ; \mathrm{A}, \mathrm{B}, \mathrm{C}(p \leq 0.01)$; Values in the same column with the same letters are significantly different: $\mathrm{X}(p \leq 0.01)$ 
K. Śmiecińska et al. (2018) 27: 243-254

An analysis of variance revealed no significant $(p>0.05)$ differences in the average values of shear force $(N)$ of beef before freezing $(A, B, C, D)$ (Table 5). Meat frozen immediately $\left(A^{1}\right)$ had higher $(p \leq 0.01)$ shear force values than the remaining samples $\left(B^{1}, C^{1}, D^{1}\right)$. Meat samples evaluated after refrigerated storage $(B, C)$ were characterized by higher $(p \leq 0.01)$ shear force values than those analyzed after frozen storage $\left(B^{1}, C^{1}\right)$.

\section{Discussion}

\section{Weight loss and water-holding capacity of meat}

Weight loss observed in meat during refrigerated and frozen storage results from the drying of the surface layer of meat due to evaporation and drip loss (Payne et al. 1998, Bustabad 1999). The results of studies investigating the effect of MA composition on weight loss and drip loss in stored meat are inconclusive. Clausen et al. (2009) observed no clear correlation between weight loss and MA composition, which is consistent with our findings. Lindahl et al. (2010) and Sekar et al. (2006) reported lower drip loss in beef packaged under MA composed of $80 \% \mathrm{O}_{2}+20 \% \mathrm{CO}_{2}$ than in vacuum-packaged beef. According to Zakrys-Waliwander et al. (2012), meat storage in $\mathrm{MA}$ with high $\mathrm{O}_{2}$ content contributes to greater drip loss, which is associated with increased susceptibility of proteins to oxidation.

A break in the integrity of the cell membrane and decreased water retention by myofilaments during meat storage in the freezer may lead to a significant increase in weight loss and thawing drip loss, which can induce changes in the quality of frozen meat. In the present study, weight loss after frozen storage was low, also when compared with that observed after refrigerated MA storage. However, drip loss leading to weight loss could have taken place after storage. This is confirmed by the high average values of weight loss in beef frozen immediately, without prior storage. Domaradzki et al. (2011) found that 30-day frozen storage had no significant effect on cooking loss in the bovine LL muscle. In a study by Vieira et al. (2009), frozen storage for 30, 75 and 90 days had no influence on weight loss in the longissimus thoracis muscle, whereas cooking loss increased significantly $(p \leq 0.01)$. In the current experiment, only drip loss was greater in meat stored in the freezer than in the refrigerator. Weight loss, cooking loss and the water-holding capacity of meat (Grau and Hamm method) were comparable before freezing and after frozen storage, which points to the high quality of beef and suggests that the parameters of the freezing process and storage conditions were adequate.

\section{$\mathrm{pH}$ of meat}

During cold storage under $\mathrm{MA}$, the $\mathrm{pH}$ of meat may be affected by $\mathrm{CO}_{2}$ present in the package. The water-solubility of $\mathrm{CO}_{2}$ increases with a decrease in temperature. In meat stored in $\mathrm{MA}$, part of $\mathrm{CO}_{2}$ dissolves in water (meat juice) to form carbonic acid $\mathrm{H}_{2} \mathrm{CO}_{3}$ which undergoes dissociation, thus decreasing the $\mathrm{pH}$ of meat (Jacobsen and Bertelsen 2002, Sørheim et al. 2004). However, according to Vergara and Gallego (2001), and Sørheim et al. (2004), the effect exerted by $\mathrm{CO}_{2}$ on the $\mathrm{pH}$ of meat varies depending on $\mathrm{CO}_{2}$ concentration in $\mathrm{MA}$. In the present study, no significant differences in the $\mathrm{pH}$ of meat were observed between samples stored under MA containing 30 and $40 \% \mathrm{CO}_{2}$. This could be due to the fact that both concentrations of $\mathrm{CO}_{2}$ and the difference between them were too low to significantly affect the $\mathrm{pH}$ of beef.

The optimal ultimate $\mathrm{pH}$ of beef should range from 5.4 to 5.8 (Page et al. 2001, Viljoen et al. 2002). In the current experiment, the $\mathrm{pH}$ of all samples was normal, which points to the high quality of beef analyzed after frozen storage. The $\mathrm{pH}$ of frozen samples did not change relative to fresh meat and meat stored in the refrigerator. This indicates that fresh beef was characterized by high quality, and that the parameters of the freezing process and frozen storage were set appropriately. Domaradzki et al. (2011) and Pietrasik and Janz (2009) also found that freezing and frozen storage had no effect on the $\mathrm{pH}$ of beef.

\section{Lipid oxidation}

Lipid oxidation can lead to a significant deterioration in the quality of meat, or even spoilage. The adverse changes resulting from lipid oxidation can be prevented by maintaining adequate storage conditions (Lavieri and Williams 2014, Mancini and Ramanathan 2014, Rogers et al. 2014), i.e. low temperature and proper packaging, to limit enzyme activity.

A decrease in the oxidative stability of lipids in meat stored in $\mathrm{MA}$ with high $\mathrm{O}_{2}$ content has been reported by many authors (Imazaki et al. 2012, Murphy et al. 2013, Rogers et al. 2014). Oxidative changes in meat are also affected by cattle breed. 
Imazaki et al. (2013) found that the extent of lipid oxidation was lesser in meat from BB cattle than in meat from Limousin cattle. According to Wood et al. (2004), red muscle fibers are more susceptible to lipid oxidation because they have a higher content of iron and unsaturated phospholipids than white muscle fibers (which predominate in BB cattle).

Frozen storage can more effectively inhibit adverse oxidative changes in meat lipids than refrigerated storage. Vieira et al. (2009) found no significant changes in TBARS values in vacuum-packaged beef that was stored in the freezer for 30 and 75 days. Only beef stored for 3 months was characterized by higher $(p \leq 0.05)$ TBARS values than fresh meat. In the present study, a decrease in the oxidative stability of lipids (an increase in TBARS values) was noted in beef packaged under $\mathrm{MA}$ without $\mathrm{O}_{2}$, and stored in the refrigerator. Frozen storage contributed to a decrease in TBARS values. The smallest oxidative changes were observed in vacuum-packaged meat. Our results are difficult to compare with the findings of other authors due to the use of different TBARS assay methods, different slaughter conditions and post-slaughter handling (time of carcass chilling), which could lead to differences in TBARS values.

\section{Color parameters of meat}

The color of meat surface and subsurface layers changes during storage. The optimization of storage parameters in view of meat type and muscle type is required to preserve a desirable and stable color of meat (Mancini et al. 2005, Vieira et al. 2009, Esmer et al. 2011, Lindahl 2011). Meat color is determined by the composition and concentration of muscle pigments. In the current study, the changes in beef color were a natural consequence of changes in muscle pigments. During storage, meat color is largely determined by chemical transformations of myoglobin, the primary pigment of muscle tissues (Mancini and Hunt 2005, Mancini et al. 2008). The rate of those changes and, consequently, meat color, are affected by the concentrations of hydrogen ions $(\mathrm{pH}), \mathrm{O}_{2}$ availability, temperature, access to light, tissue structure, the activity of reducing enzymes, and lipid oxidation (Mancini et al. 2011, Nassu et al. 2012, Pastsart et al. 2013). Esmer et al. (2011), Lindahl (2011), Ramanathan et al. (2011), Imazaki et al. (2012), Resconi et al. (2012) and Rogers et al. (2014) pointed to an adverse effect of MA containing $\mathrm{O}_{2}$ on the process of meat color development. In the cited studies, the process of metmyoglobin formation was reflected in a decrease in the value of parameter $a^{*}$ and a simultaneous increase in the value of parameter $\mathrm{h}^{\circ}$. In meat samples stored under "anaerobic" conditions, an increase was noted in the contribution of redness and yellowness, and color saturation. In our study, the contribution of redness and yellowness, and color saturation also increased in meat samples stored in the refrigerator, relative to those evaluated before storage. In frozen beef, the changes in muscle pigments led to a decrease in yellowness, redness and color saturation, and an increase in hue angle, compared with meat samples analyzed before freezing (after storage in the refrigerator). Such relationships were also observed by Vieira et al. (2009) in the longissimus thoracis muscle after 90 days of frozen storage. The changes in meat color parameters, noted in the present and other studies, point to metmyoglobin formation in frozen meat. Jeong et al. (2011) also found that frozen/thawed meat was characterized by a lower contribution of redness and yellowness, lower oxymyoglobin content, and higher metmyoglobin content.

\section{Sensory properties and shear force values}

The rate and extent of changes in the sensory quality of meat are determined by meat handling before packaging, the composition of gas mixture in MA packaging, and the time and method of meat storage (Brewer and Novakofski 2008, Zakrys et al. 2009, Zhou et al. 2010, Resconi et al. 2012, Vitale et al. 2014). Changes in the sensory properties of meat are observed even under optimal storage conditions, mostly due to lipid oxidation (Lagerstedt et al. 2007, Warren et al. 2008, Zakrys et al. 2008) and protein transformations (Lund et al. 2007, Iwanowska et al. 2010, Kim et al. 2010a).

Clausen et al. (2009) demonstrated that the warmed-over flavor (WOF) developed more frequently $(p \leq 0.001)$ in samples of the bovine LD muscle stored under MA containing $\mathrm{O}_{2}$ than in those stored in vacuum packaging and air. According to the cited authors, Jayasingh et al. (2002) and Resconi et al. (2012), the development of WOF is correlated with high average TBARS values. In the present study, the deterioration in the flavor of beef stored in the freezer, compared with meat samples stored in the refrigerator for 14 days, was not related to the oxidation of fatty acids because TBARS values were low. However, it should be stressed that frozen meat scored more than 4 points for aroma and taste (on a 5-point scale).

The results of studies investigating the effect of frozen storage on beef texture are ambiguous. According to Shanks et al. (2002), frozen storage improves beef tenderness, which is particularly important in meat that is not subjected to the aging process. Domaradzki et al. (2011) reported that frozen storage caused a significant $(p \leq 0.01)$ 
K. Śmiecińska et al. (2018) 27: 243-254

decrease in shear force values, compared with non-frozen meat. In our study, frozen storage also had a beneficial influence on beef tenderness, which was reflected by a decrease in shear force values. In contrast, Litwińczuk et al. (2005) demonstrated that beef stored in the freezer for 60 days was characterized by higher shear force values than meat stored in the refrigerator. Kołczak et al. (2005) did not observe significant changes in the texture of frozen/thawed beef, but noted a decrease in its tenderness (an increase in shear force values) relative to fresh meat.

\section{Conclusions}

Both refrigerator and freezer storage of meat frozen after 14 days of MA storage affected weight loss and the WHC of meat. Weight loss and cooking loss were smaller, and drip loss was greater after frozen storage compared with refrigerated storage. The $\mathrm{pH}$ of meat stored in the refrigerator and freezer was typical of high-quality beef. TBARS values increased (the oxidative stability of lipids decreased) after MA storage and decreased after frozen storage. Differences in the contribution of redness $\left(a^{*}\right)$ and yellowness $\left(b^{*}\right)$ in the analyzed meat samples led to differences in the average values of chroma $\left(C^{*}\right)$ and hue angle $\left(h^{\circ}\right)$. The changes in color parameters point to metmyoglobin formation in frozen meat. The aroma and taste of beef deteriorated after frozen storage. Both refrigerator and freezer storage had a beneficial influence on tenderness, and shear force values decreased in frozen beef. The composition of MA during refrigerated storage had no effect on the analyzed parameters of beef. Frozen meat that was stored in a MA containing Ar prior to freezing was characterized by the lowest weight loss, and vacuum-packaged meat - by the lowest TBARS values.

\section{References}

Aldai, N., Lavin, P., Kramer, J.K.G., Jaroso, R. \& Mantecón, A.R. 2012. Breed effect on quality veal production in mountain areas: emphasis on meat fatty acid composition. Meat Science 92: 687-696. http://dx.doi.org/10.1016/j.meatsci.2012.06.024

Aldai, N., Nájera, A.I., Dugan, M.E.R., Celaya, R. \& Osoro, K. 2007. Characterization of intramuscular, intermuscular and subcutaneous adipose tissues in yearling bulls of different genetic groups. Meat Science 76: 682-691. https://doi.org/10.1016/j.meatsci.2007.02.008

Arvanitoyannis, I.S. \& Stratakos, A.Ch. 2012. Application of modified atmosphere packaging and active/smart technologies to red meat and poultry: A Review. Food Bioprocess Technology 5: 1423-1446. https://doi.org/10.1007/s11947-012-0803-z

Baryłko-Pikielna, N., Kossakowska, T. \& Baldwin, Z. 1964. Wybór optymalnej metody przygotowania mięsa wołowego i wieprzowego do oceny sensorycznej. Roczniki Instytutu Przemysłu Mięsnego 1: 132-139. (in Polish).

Brewer, M.S. \& Novakofski, J.E. 2008. Consumer sensory evaluations of aging effects on beef quality. Journal of Food Science 73: 78-82. https://doi.org/10.1111/j.1750-3841.2007.00575.x

Brooks, J.C., Alvarado, M., Stephens, T.P., Kellermeier, J.D., Tittor, A.W., Miller, M.F. \& Brashears, M.M. 2008. Spoilage and safety characteristics of ground beef packaged in traditional and modified atmosphere packages. Journal of Food Protection 71: 293301. https://doi.org/10.4315/0362-028X-71.2.293

Bustabad, O.M. 1999. Weight loss during freezing and the storage of frozen meat. Journal of Food Engineering 41: 1-11. https:// doi.org/10.1016/S0260-8774(99)00065-5

Cayuela, J.M., Gil, M.D., Bañón, S. \& Garrido, M.D. 2004. Effect of vacuum and modified atmosphere packing on the quality of pork loin. European Food Research and Technology 219: 316-320. https://doi.org/10.1007/s00217-004-0970-x

Christensen, M., Ertbjerg, P., Failla, S., Sañudo, C., Richardson, R.I., Nute, G.R., Olleta, J.L., Panea, B., Alberti, P., Juárez, M., Hocquette, J.F. \& Williams, J.L. 2011. Relationship between collagen characteristics, lipid content and cooked texture of meat from young bulls of fifteen European breeds. Meat Science 87: 61-65. https://doi.org/10.1016/j.meatsci.2010.09.003

Clausen, I., Jacobsen, M., Ertbjerg, P. \& Madsen, T.N. 2009. Modified atmosphere packaging affects lipid oxidation, myofibrillar fragmentation index and eating quality of beef. Packaging Technology and Science 22: 85-96. https://doi.org/10.1002/pts.828

Commission Internationale de l'Eclairage (CIE) 1978. Recommendations on uniform color spaces, color difference equations, psychometric color terms. Supplement No. 2 to CIE Publication No. 15 (E-1.3.1.) 1971/(TC-1-3), Bureau Central de la CIE, Paris, 1978.

Cuvelier, C., Clinquart, A., Hocquette, J.F., Cabaraux, J.F., Dufrasne, I., Istasse, L. \& Hornick, J.L. 2006. Comparison of composition and quality traits of meat from young finishing bulls from Belgian Blue, Limousin and Aberdeen Angus breeds. Meat Science 74: 522-531. https://doi.org/10.1016/j.meatsci.2006.04.032

Daszkiewicz, T., Hnatyk, N., Dąbrowski, D., Janiszewski, P., Gugołek, A., Śmiecińska, K., Winarski, R. \& Koba-Kowalczyk, M. 2015. A comparison of the quality of the Longissimus lumborum muscle from wild and farm-raised fallow deer (Dama dama L.). Small Ruminant Research 129: 77-83. https://doi.org/10.1016/j.smallrumres.2015.05.003

Daszkiewicz, T., Kubiak, D., Winarski, R. \& Koba-Kowalczyk, M. 2012. The effect of gender on the quality of roe deer (Capreolus capreolus L.) meat. Small Ruminant Research 103: 169-175. https://doi.org/10.1016/j.smallrumes.2011.09.044

Domaradzki, P., Skałecki, P., Florek, M. \& Litwińczuk, A. 2011. Wpływ przechowywania zamrażalniczego na właściwości fizykochemiczne mięsa wołowego pakowanego próżniowo Żywność. Nauka. Technologia. Jakość 4: 117-126. (in Polish).

Dransfield, E. 2008. The taste of fat. Meat Science 80: 37-42. https://doi.org/10.1016/j.meatsci.2008.05.030 
Dubost, A., Micol, D., Picard, B., Lethias, C., Andueza, D., Bauchart, D. \& Listrat, A. 2013. Structural and biochemical characteristics of bovine intramuscular connective tissue and beef quality. Meat Science 95: 555-561. https://doi.org/10.1016/j.meatsci.2013.05.040

Esmer, O.K., Irkin, R., Degirmencioglu, N. \& Degirmencioglu, A. 2011. The effects of modified atmosphere gas composition on microbiological criteria, color and oxidation values of minced beef meat. Meat Science 88: 221-226. https://doi.org/10.1016/j. meatsci.2010.12.021

Farouk, M.M. \& Wieliczko, K.J. 2003. Optimum time for using chilled beef in gelled products. Journal of Food Science 68: 164-167. https://doi.org/10.1111/j.1365-2621.2003.tb14134.x

Honikel, K.O. 1998. Reference Methods for the Assessment of Physical Characteristics of Meat. Meat Science 49: 447-457. https://doi.org/10.1016/S0309-1740(98)00034-5

Imazaki, P.H., Tahiri, A., Thimister, J. \& Clinquart, A. 2013. Influence of breed and previous storage time on color and lipid stability of beef packaged in high-oxygen atmosphere. In: 59th International Congress of meat Science and Technology. Izmir, Turkey. https://orbi.uliege.be/bitstream/2268/156475/1/IMAZAKI_ICoMST2013_Breed_effect.pdf

Imazaki, P.H., Tahiri, A., Thimister, J., Scippo, M.L. \& Clinquart, A. 2012. Effect of duration and temperature of previous vacuum packed storage on the oxidative stability of Belgian Blue meat packed in high-oxygen atmosphere. In: 58th International Congress of meat Science and Technology. Montreal, Canada. https://orbi.uliege.be/bitstream/2268/131255/1/Imazaki_ICoMST_2012_effect_time_temperature_VP_oxidative_stability_BBB_MAP_FV.pdf

ISO 2012. Sensory Analysis - General guidelines for the selection, training and monitoring of selected assessors and expert sensory assessors. ISO 8586: 2012. International Organization for Standarization, Geneva, Switzerland.

Iwanowska, A., Iwańska, E., Grześ, B., Mikołajczak, B., Pospiech, E., Rosochacki, S., Juszczak-Kubiak, E. \& Łyczyński, A. 2010. Changes in proteins and tenderness of meat from young bulls of four breeds at three ages over 10 days of cold storage. Animal Science Papers and Reports 28: 13-25.

Jacobsen, M. \& Bertelsen, G. 2002. The use of $\mathrm{CO}_{2}$ in packaging of fresh red meats and its effect on chemical quality changes in the meat: A review. Journal of Muscle Foods 13: 143-168. https://doi.org/10.1111/j.1745-4573.2002.tb00326.x

Jayasingh, P., Cornforth, D.P., Brennand, C.P., Carpenter, C.E. \& Whittier, D.R. 2002. Sensory evaluation of ground beef stored in high-oxygen modified atmosphere packaging. Journal of Food Science 67: 3493-3496. https://doi.org/10.1111/j.1365-2621.2002. tb09611.x

Jeong, J.Y., Kim, G.D., Yang, H.S. \& Joo, S.T. 2011. Effect of freeze-thaw cycles on physicochemical properties and color stability of beef semimembranosus muscle. Food Research International 44: 3222-3228. https://doi.org/10.1016/j.foodres.2011.08.023

Keady, S.M., Kenny, D.A., Ohlendieck, K., Doyle, S., Keane, M.G. \& Waters, S.M. 2013. Proteomic profiling of bovine M. longissimus lumborum from crossbred Aberdeen Angus and Belgian Blue sired steers varying in genetic merit for carcass weight. Journal of Animal Science 91: 654-665. https://doi.org/10.2527/jas.2012-5850

Kim, Y.H., Huff-Lonergan, E., Sebranek, J.G. \& Lonergan, S.M. 2010a. High-oxygen modified atmosphere packaging system induces lipid and myoglobin oxidation and protein polymerization. Meat Science 85: 759-767. https://doi.org/10.1016/j.meatsci.2010.04.001

Kim, E.J., Richardson, R.L., Lee, M.R.F., Gibson, K. \& Scollan, N.D. 2010b. Effect of lipid-rich plant extract on the fatty acids composition and meat quality of Belgian-Blue cross bred steers. Proceedings of the British Society of Animal Science 1: 131. https:// doi.org/10.1017/S2040470010002748

Kołczak, T., Palka, K. \& Łącki, J. 2005. Water retention, shear force and texture parameters of cattle psoas and semitendinosus muscles unfrozen and frozen during post-mortem ageing. Polish Journal of Food and Nutrition Sciences 1: 17-26.

Lagerstedt, Å., Edblad, U., Wretström, S., Enfält, L., Johansson, L. \& Lundström, K. 2007. Minced meat packed in high-oxygen modified atmosphere - effects on sensory quality and oxidation products. In: 53th international congress of meat science and technology. Beijing, China, p. 515-516.

Lagerstedt, Å., Enfält, L., Johansson, L. \& Lundström, K. 2008. Effect of freezig on sensory quality, shear force and water loss in beef $M$. longissimus dorsi. Meat Science 80: 457-461. https://doi.org/10.1016/j.meatsci.2008.01.009

Lavieri, N. \& Wiliams, S.K. 2014. Effects of packaging systems and fat concentrations on microbiology, sensory and physical properties of ground beef stored at $4 \pm 1^{\circ} \mathrm{C}$. Meat Science 97: 534-541. https://doi.org/10.1016/j.meatsci.2014.02.014

Lepetit, J. 2008. Collagen contribution to meat toughness: Theoretical aspects. Meat Science 80: 960-967. https://doi.org/10.1016/j. meatsci.2008.06.01

Leygonie, C., Britz, T.J. \& Hoffman, L.C. 2012. Impact of freezing and thawing on the quality of meat: Review. Meat Science 91: 93-98. https://doi.org/10.1016/j.meatsci.2012.01.013

Li, K., Zhang, Y., Mao, Y., Cornforth, D., Dong, P., Wang, R., Zhu, H. \& Luo, X. 2012. Effect of very fast chilling and aging time on ultra-structure and meat quality characteristics of Chinese Yellow cattle M. longissimus lumborum. Meat Science 92: 795-804. https://doi.org/10.1016/j.meatsci.2012.07.003

Lindahl, G. 2011. Colour stability of steaks from large beef cuts aged under vacuum or high oxygen modified atmosphere. Meat Science 87: 428-435. https://doi.org/10.1016/j.meatsci.2010.10.023

Lindahl, G., Lagerstedt, Ä., Ertbjerg, P., Samples, S. \& Lundström, K. 2010. Ageing of large cuts of beef loin in vacuum or high oxygen modified atmosphere - effect on shear force, calpain activity, desmin degradation and protein oxidation. Meat Science 85: 160-166. https://doi.org/10.1016/j.meatsci.2009.12.020

Litwińczuk, Z., Florek, M. \& Ryszkowska-Siwko, M. 2005. Changes in beef meat colour and tenderness after different cold storage and freezing periods. Annals of Animal Science 2: 91-94.

Lund, M.N., Hviid, M.S. and Skibsted, L.H. 2007. The combined effect of antioxidants and modified atmosphere packaging on protein and lipid oxidation in beef patties during chill storage. Meat Science 76: 226-233. https://doi.org/10.1016/j.meatsci.2006.11.003 
Mancini, R.A. \& Hunt, M.C. 2005. Current research in meat color. Meat Science 71: 100-121. https://doi.org/10.1016/j.meatsci.2005.03.003

Mancini, R.A., Hunt, M.C., Hachmeister, K.A., Kropf, D.H. \& Johnson, D.E. 2005. Exclusion of oxygen from modified atmosphere packages limits beef rib and lumbar vertebrae marrow discoloration during display and storage. Meat Science 69: 493-500. https://doi.org/10.1016/j.meatsci.2004.09.003

Mancini, R.A. \& Ramanathan, R. 2014. Effects of postmortem storage time on color and mitochondria in beef. Meat Science 98 : 65-70. https://doi.org/10.1016/j.meatsci.2014.04.007

Mancini, R.A., Ramanathan, R., Suman, S.P., Dady, G. \& Joseph, P. 2011. Effects of succinate on ground beef color and premature browning. Meat Science 89: 189-194. https://doi.org/10.1016/j.meatsci.2011.04.016

Mancini, R.A., Seyfert, M. \& Hunt, M.C. 2008. Effects of data expression, sample location and oxygen partial pressure on initial nitric oxide metmyoglobin formation and metmyoglobin-reducing-activity measurement in beef muscle. Meat Science 79: 244251. https://doi.org/10.1016/j.meatsci.2007.09.008

McMillin, K.W. 2008. Where is MAP going? A review and future potential of modified atmosphere packaging for meat. Meat Science 80: 43-65. https://doi.org/10.1016/j.meatsci.2008.05.028

Murphy, K.M., O'Grady, M.N. \& Kerry, J.P. 2013. Effect of varying the gas headspace to meat ratio on the quality and shelf-life of beef steaks packaged in high oxygen modified atmosphere packs. Meat Science 94: 447-454. https://doi.org/10.1016/j.meatsci.2013.03.032

Nassu, R.T., Uttaro, B., Aalhus, J.L., Zawadski, S., Juarez, M. \& Dugan, M.E.R. 2012. Type of packaging affects the colour stability of vitamin E enriched beef. Food Chemistry 135: 1868-1872. https://doi.org/10.1016/j.foodchem.2012.06.055

Ngapo, T.M., Riendeau, L., Laberge, C. \& Fortin, J. 2012b. “Chilled” pork - Part II: Consumer perception of sensory quality. Meat Science 92: 338-345. https://doi.org/10.1016/j.meatsci.2012.04.031

Ngapo, T.M., Riendeau, L., Laberge, C., Leblanc, D. \& Fortin, J. 2012a. “Chilled" pork - Part I: Sensory and physico-chemical quality. Meat Science 92: 330-337. https://doi.org/10.1016/j.meatsci.2012.04.032

Olivera, D.F., Bambicha, R., Laporte, G., Cárdenas, F.C. \& Mestorino, N. 2013. Kinetics of colour and texture changes of beef during storage. Journal of Food Science and Technology 50: 821-825. https://doi.org/10.1007/s13197-012-0885-7

Page, J.K., Wulf, D.M. \& Schwotzer, T.R. 2001. A survey of beef muscle color and pH. Journal of Animal Science 79: 678-687. https://doi.org/10.2527/2001.793678x

Pastsart, U., De Boever, M., Claeys, E. \& De Smet, S. 2013. Effect of muscle and post-mortem rate of pH and temperature fall on antioxidant enzyme activities in beef. Meat Science 93: 681-686. https://doi.org/10.1016/j.meatsci.2012.11.008

Payne, S.R., Durham, C.J., Scott, S.M. \& Devine, C.E. 1998. The effects of non-vacuum packaging systems on drip loss from chilled beef. Meat Science 49: 277-287. https://doi.org/10.1016/S0309-1740(97)00135-6

Peña, F., Molina, A., Avilés, C., Juárez, M. \& Horcada, A. 2013. Marbling in the longissimus thoracis muscle from lean cattle breeds. Computer image analysis of fresh versus stained meat samples. Meat Science 95: 512-519. https://doi.org/10.1016/j. meatsci.2013.05.036

Pietrasik, Z. \& Janz, J.A.M. 2009. Influence of freezing and thawing on the hydration characteristics, quality, and consumer acceptance of whole muscle beef injected with solutions of salt and phosphate. Meat Science 81: 523-532. https://doi.org/10.1016/j. meatsci.2008.10.006

Pikul, J., Leszczyński, D.E. \& Kummerow, F.A. 1989. Evaluation of three modified TBA methods for measuring lipid oxidation in chicken meat. Journal Agricultural Food Chemistry 37: 1309-1313. https://doi.org/10.1021/jf00089a022

Purslow, P.P., Archile-Contreras, A.C. \& Cha, M.C. 2012. Meat science and muscle biology symposium: manipulating meat tenderness by increasing the turnover of intramuscular connective tissue. Journal of Animal Science 90: 950-959. https://doi. org/10.1021/jf00089a022

Ramanathan, R., Mancini, R.A. \& Dady, G.A. 2011. Effects of pyruvate, succinate, and lactate enhancement on beef longissimus raw color. Meat Science 88: 424-428. https://doi.org/10.1016/j.meatsci.2011.01.021

Resconi, V.C., Escudero, A., Beltrán, J.A., Olleta, J.L., Sañudo, C. \& Del Mar Campo M.D. 2012. Color, lipid oxidation, sensory quality, and aroma compounds of beef steaks displayed under different levels of oxygen in a modified atmosphere package. Journal of Food Science 71: 10-18. https://doi.org/10.1111/j.1750-3841.2011.02506.x

Rogers, H.B., Brooks, J.C., Martin, J.N., Tittor, A., Miller, M.F. \& Brashears, M.M. 2014. The impact of packaging system and temperature abuse on the shelf life characteristics of ground beef. Meat Science 97: 1-10. https://doi.org/10.1016/j.meatsci.2013.11.020

Sekar, A., Dushyanthan, K., Radhakrishnan, K.T. \& Narendra Babu, R. 2006. Effect of modified atmosphere packaging on structural and physical changes in buffalo meat. Meat Science 72: 211-215. https://doi.org/10.1016/j.meatsci.2005.07.003

Shanks, B.C., Wulf, D.M. \& Maddock, R.J. 2002. Technical note: The effect of freezing on Warner-Bratzler shear force values of beef longissimus steaks across several postmortem ageing periods. Journal of Animal Science 80: 2122-2125. https://doi.org/10.1093/ ansci/80.8.2122

Sørheim, O., Ofstad, R. \& Lea, P. 2004. Effects of carbon dioxide on yield, texture and microstructure of cooked ground beef. Meat Science 67: 231-236. https://doi.org/10.1016/j.meatsci.2003.10.010

StatSoft, Inc. 2012. Statistica (data analysis software system), version 12.0. StatSoft, Inc., Tulsa, OK, USA. www.statsoft.com.

van Oeckel, M.J., Warnants, N. \& Boucquee, Ch.V. 1999. Comparison of different methods for measuring water holding capacity and juiciness of pork versus on-line screening methods. Meat Science 51: 313-320. https://doi.org/10.1016/S0309-1740(98)00123-5

Vergara, H. \& Gallego, L. 2001. Effects of gas composition in modified atmosphere packaging on the meat quality of Spanish Manchega lambs. Journal Science Food Agriculture 81: 1353-1357. https://doi.org/10.1002/jsfa.953 
Viana, E.S., Gomide, L.A.M. \& Vanetti, M.C.D. 2005. Effect of modified atmospheres on microbiological, color and sensory properties of refrigerated pork. Meat Science 71: 696-705. https://doi.org/10.1016/j.meatsci.2005.05.013

Vieira, C., Diaz, M.T., Martinez, B. \& Garcia-Cachan, M.D. 2009. Effect of frozen storage conditions (temperature and length of storage) on microbiological and sensory quality of rustic crossbred beef at different states of ageing. Meat Science 83: 398-404. https://doi.org/10.1016/j.meatsci.2009.06.013

Viljoen, H.F., De Kock, H.L. \& Webb, E.C. 2002. Consumer acceptability of dark, firm and dry (DFD) and normal pH beef steaks. Meat Science 61: 181-185.https://doi.org/10.1016/S0309-1740(01)00183-8

Vitale, M., Pérez-Juan, M., Lloret, E., Arnau, J. \& Realini, C.E. 2014. Effect of aging time in vacuum on tenderness, and color and lipid stability of beef from mature cows during display in high oxygen atmosphere package. Meat Science 96: 270-277. https:// doi.org/10.1016/j.meatsci.2013.07.027

Warren, H.E., Scollan, N.D., Nute, G.R., Huges, S.I., Wood, J.D. \& Richardson, R.I. 2008. Effects of breed and a concentrate or grass silage diet on beef quality in cattle of 3 ages. II: Meat stability and flavor. Meat Science 78: 270-278. https://doi.org/10.1016/j. meatsci.2007.06.007

Wiener, P., Woolliams, J.A., Frank-Lawale, A., Ryan, M., Richardson, R.I., Nute, G.R., Wood, J.D, Homer, D. \& Williams, J.L. 2009. The effects of a mutation in the myostatin gene on meat and carcass quality. Meat Science 83: 127-134. https://doi.org/10.1016/j. meatsci.2009.04.010

Wood, J.D., Nute, G.R., Richardson, R.I., Whittington, F.M., Southwood, O., Plastow, G., Mansbride, R., Da Costa, N. \& Chang, K.C. 2004. Effects of breed, diet and muscle on fat deposition and eating quality in pigs. Meat Science 67: 651-667. https://doi. org/10.1016/j.meatsci.2004.01.007

Zakrys, P.I., Hogan, S.A., O'Sullivan, M.G, Allen, P. \& Kerry, J.P. 2008. Effects of oxygen concentration on the sensory evaluation and quality indicators of beef muscle packed under modified atmosphere. Meat Science 79: 648-655. https://doi.org/10.1016/j. meatsci.2007.10.030

Zakrys, P.I., O'Sullivan, M.G, Allen, P. \& Kerry, J.P. 2009. Consumer acceptability and physiochemical characteristics of modified atmosphere packed beef steaks. Meat Science 81: 720-725. https://doi.org/10.1016/j.meatsci.2008.10.024

Zakrys-Waliwander, P.I., O'Sullivan, M.G., O'Neill, E.E. \& Kerry, J.P. 2012. The effects of high oxygen modified atmosphere packaging on protein oxidation of bovine $M$. longissimus dorsi muscle during chilled storage. Food Chemistry 131: 527-532. https:// doi.org/10.1016/j.foodchem.2011.09.017

Zhou, G.H., Xu, X.L. \& Liu, Y. 2010. Preservation technologies for fresh meat - A review. Meat Science 86: 119-128. https://doi. org/10.1016/j.meatsci.2010.04.033 